0-057 磁場誘導方式を用いた胸腔鏡手術用ナビゲ ーションシステムの開発

京都府立医科大学 呼吸器外科

島田 順一, 加藤 大志朗, 柳田 正志, 寺内 邦彦, 西村 元宏, 井伊 庸弘, 戸田 省吾

CT診断技術の向上によりミリ単位の微小肺病変の切除の 機会は急速に増加している。これらの病変のうち視認, 触 知が困難と思われる症例については, 術前に病変部近傍に マーキングを行い，これを目標にして切除手術を行ってき た。しかしそうして得られる位置情報は診断された腫瘤の サイズに比べ格段に誤差が大きいのが現状である，本研究 で実現しようとする腫瘍位置ナビゲーションシステムは, 病変部に埋め込んだ発信機からの信号により内視鏡や鉏子 などを誘導・制御しここれにより得られた位置情報をもと に腫瘍を的確に切除しょうとするものである．以上の胸腔 鏡手術システムが実現できれば，位置検出システムで算出 した視認不能な病変部も鉗子との位置情報をモニター画像 上へ表示しながら手術することが可能となる。本研究の基 礎として，発信機の信号として生体内を透過可能である磁 場を採用し，この磁場の強さと方向をわずか 5 ミリ長のフ ラックスゲート型センサ（新規開発）で検知し3次元的に 発生磁場を解析することにより発信機（磁石）の位置を算 出することに成功した。今後, 本システムの精度をあげ, 臨床応用をすることで，肺の微小病変の正確な局所切除術 を実現したい。

\section{O-058 胸腔鏡下肺悪性腫瘍手術の成績}

'東海大学 医学部 外科学系 呼吸器外科学部門, ${ }^{2}$ 国立 療養所富士.病院

岩㠃 正之', 加藤 暢介', 武市 悠', 増田大介', 中川 知已!, 早川 信崇!, 増田 良太 ${ }^{1}$, 吉野 和穂 ', 藤森 賢!, 濱本 篤!, 酒瀬川 浩一', 西海 昇 !, 山田 俊介'，加賀 基知三 ${ }^{2}$ ，井上 宏司

【目的】低侵襲手術として胸腔鏡下肺悪性腫瘍手術を開発 してきた。この手術方法が予後に寄与しているか否かを検 討した。【方法】1994年1月から1999年12月までの間に当 院で胸腔鏡下手術を施行し術後 3 年を経過した術前診断 I A 期肺癌 162 例を対象とした。【結果】リンパ節郭清 NDO (部分切除及び区域切除) が 22 例（3生率 58.8\%，5生率 $42.0 \%$ ), ND1（肺葉切除）が 29 例 (3生率71.6\%，5生率 $71.6 \%$ ), ND2（肺葉切除＋縦隔郭清）が 111 例（3生率 $93.5 \% ， 5$ 生率 $89.3 \%$ ) であった. ND2症例の病理学的検 索後の内訳は，N0が81例（3生率 $98.7 \% ， 5$ 生率 $94.0 \%$ ）, $\mathrm{N} 1$ が 9 例 (3生率 $88.9 \%, 5$ 生率 $56.5 \%), \mathrm{N} 2$ が 21 例（3 生率 $85.6 \%$ ，5生率 $65.6 \%$ ）であった。【結論】術前診断 I A 期肺癌症例には, 胸腔鏡下肺悪性腫瘍手術の適応があ る。縦隔リンパ節転移症例でも顕微鏡的転移症例の予後は 良好で, 縦隔郭清の予後への寄与は大きいと考える。

\section{O-059 GGO病変に対する胸腔鏡下手術における 術中標本軟線撮影の意義}

! 磐田市立総合病院 呼吸器外科, “浜松医科大学 第一外
科

伊藤 靖', 大井 諭', 鈴木 一也”

【目的】CTで発見される小型の G.G.O.を呈する病変に対す る胸腔鏡下手術では，様々な術前マーキングの工夫が報告 されている。しかし，マーキングした部分と病変の雨者が 確実に切除できているかを術中に確認することも重要であ る. 我々は, 病変を確実に採取するために術中切除肺の軟 線撮影を試みて, 有用と考えられたので報告する。【方法】 CT L p ure G.G.O.を呈する $1 \mathrm{~cm}$ 以下の肺病変に対して, 術 前 CTガイド下マーキングを行い, 胸腔鏡下肺部分切除術 を施行した。術中にManmmomat2（Siemens社）を用い て, 管電压 $28 \mathrm{kVp}$, 管電流 $25 \mathrm{mAs}$, 撮影距離 $60 \mathrm{~cm}$ で 2 倍 拡大の軟線撮影を行った. 病変部を確認した後, 画像を元 に病理医に切り出し位置を指示して, 術中迅速組織診を実 施した。【結果】軟線撮影で認められた濃度上昇域に一致 して, 病理学的にも病変が確認され, またstaple と病巣の 距離の評価が可能であった。【結論】G.G.O.病変に刘する 胸腔鏡下手術における術中軟線撮影は, 簡便で, マーキン グした部分と病変の両者が確実に切除できているかを評価 するのに有用であるとともに，病理医の切り出しの際にメ ルクマールとなる点でも有用と考えられた。

\section{O-060 高齢者（80歳以上）に対する胸腔鏡下肺} 済生会神奈川県病院 呼吸器外科

\section{青木 輝浩, 加勢田 静}

目的）胸腔鏡下手術は低侵襲と言われるが，高齢者にも安 全に行われているか検討した。対象）1997年4月から 2002 年 12 月までに胸腔鏡下肺腎性腫瘍切除を行った 80 歳以上 の患者 14 例. 結果) 症例の年齢は平均 82 歳 $(80-86)$, 男性 8 例. 女性 6 例. 術前肺機能は肺活量 $2.6 \mathrm{~L}$ (1.72$3.81)$, 一秒量 $1.8 \mathrm{~L} \quad(0.95-2.98)$, 一秒率 72.1\% (57.193.9). 血液ガス所見ではpO2 84.3 Torr $(50.6-106.0)$, pCO2 41.2 Torr (32.8-49.9). 全例何らかの既往歴があ り, 高血圧 5 例, 心筋梗塞 1 例, 狭心症で冠動脈バイパス 術 2 例，覀性腫瘍の手術 3 例等である。手術は 13 例に肺葉 切除・リンパ節郭清術が行われた。1例肺癌に対して肺葉 胸壁合併切除・リンパ節郭清術と腹部大動脈瘤人工血管置 換術の同時手術を行った。肺切除についての手術時間は 207 分 $(117-310)$. 術後の平均入院期間は 20 日 $(8-40)$ であった，術後合併症は，1例に不整脈が新しく出現した 以外には特に認めなかった。まとめ）胸腔鏡下肺葉切除は 高齢者にも安全に行われている。 